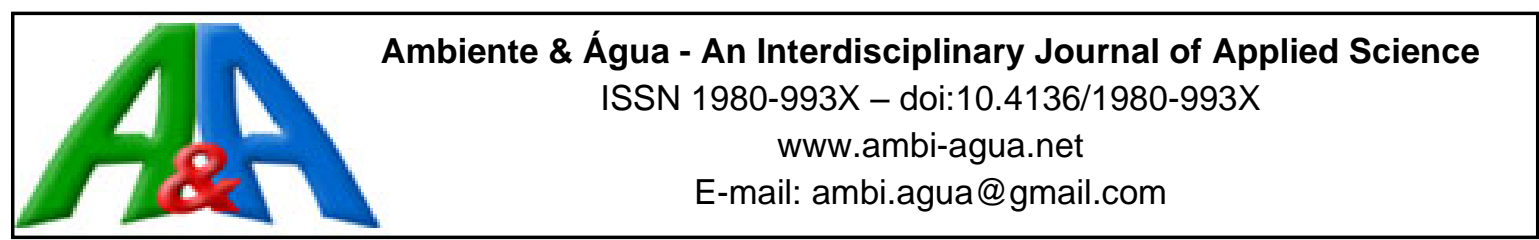

\title{
Sub-daily hydrological-hydrodynamic simulation in flash flood basins: Una river (Pernambuco/Brazil)
}

\author{
ARTICLES doi:10.4136/ambi-agua.2556
}

Received: 07 Apr. 2020; Accepted: 28 Jul. 2020

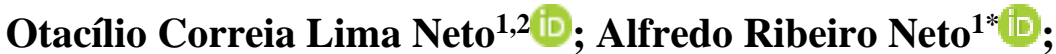 \\ Fellipe Henrique Borba Alves ${ }^{1}$; José Almir Cirilo $^{3}$ iD
}

\begin{abstract}
${ }^{1}$ Departamento de Engenharia Civil e Ambiental. Programa de Pós-Graduação em Engenharia Civil. Universidade Federal de Pernambuco (UFPE), Rua Acadêmico Hélio Ramos, s/n, Cidade Universitária, CEP: 50740-530, Recife, PE, Brazil. E-mail: otacilio.neto@cogerh.com.br, fellipehba@hotmail.com ${ }^{2}$ Núcleo Operacional da Gerência da Sub-bacia Hidrográfica do Rio Salgado. Companhia de Gestão dos Recursos Hídricos do Estado do Ceará (COGERH), Avenida Alan Kardec, n 40, CEP: 63122-295, Crato, CE, Brazil. E-mail: otacilio.neto@cogerh.com.br

${ }^{3}$ Núcleo de Tecnologia. Universidade Federal de Pernambuco (UFPE), Avenida Campina Grande, s/n, Km 59, CEP: 55014-900, Caruaru, PE, Brazil. E-mail: almir.cirilo@gmail.com *Corresponding author. E-mail: alfredo.ribeiro@ufpe.br
\end{abstract}

\begin{abstract}
Flash floods are observed in the Una River Basin, Pernambuco/Brazil. This particular type of flood is a short-duration hydrological event with occurrence of the peak flow within minutes to few hours after the onset of the rainfall, taking place typically in mountainous regions. The objective of the paper was to assess the sub-daily hydrological and hydrodynamic modeling of flood events in 2011 and 2017. Sub-daily precipitation and streamflow were applied to the models Hydrologic Engineering Center-Hydrologic Modeling System (HEC-HMS) and River Analysis System (HEC-RAS). Model evaluation methods such as Nash-Sutcliffe efficiency (NSE), percent bias, and the ratio of the root mean squared error to the standard deviation of measured data (RSR) were used in the calibration process. The maximum infiltration rate and the Snyder peak coefficient estimation were the most sensitive parameters in the hydrological model. The calibration of the HEC-HMS showed good performances (Catende station $\mathrm{NSE}=0.78$ and RSR=0.46; Palmares station NSE=0.68 and RSR=0.57). During HEC-RAS 1D flow simulations, steep regions in the Una River caused numerical instabilities. The $2 \mathrm{D}$ solution was needed to overcome this problem, allowing us to represent the water level in the city of Palmares satisfactorily.
\end{abstract}

Keywords: hydrologic modeling system, natural disasters, river analysis system, 2D simulation.

\section{Modelagem hidrológica e hidrodinâmica sub-diária em bacias de resposta rápida: Rio Una (Pernambuco/Brasil)}

\section{RESUMO}

Eventos extremos de cheia que ocorrem poucas horas após a precipitação em regiões de altas declividades, conhecidos como flash flood, são observados na bacia hidrográfica do rio Una. O artigo tem como objetivo avaliar a modelagem hidrológica e hidrodinâmica com dados sub-diários dos maiores eventos de cheia da bacia do rio Una nos anos de 2011 e 2017. 
Precipitação e vazão sub-diárias foram utilizadas nos modelos Hydrologic Engineering CenterHydrologic Modeling System (HEC-HMS) e River Analysis System (HEC-RAS). A calibração foi avaliada pela eficiência de Nash-Sutcliffe (NSE), percentual de tendência e a razão dada pelo erro quadrático médio pelo desvio padrão dos dados observados (RSR). Os parâmetros taxa de infiltração máxima e coeficiente de pico do método HU Snyder apresentaram maior sensibilidade na calibração do HEC-HMS. A calibração exibiu um bom desempenho (estação Catende NSE=0.78, RSR=0.46; estação Palmares NSE=0.68, RSR=0.57). O modelo hidrodinâmico unidimensional apresentou instabilidades devido às regiões íngremes da bacia. A solução 2D foi necessária para superar esse problema, o que permitiu representar satisfatoriamente o nível da água na cidade de palmares.

Palavras-chave: desastres naturais, simulação 2D, sistema de análise de rio, sistema de modelagem hidrológica.

\section{INTRODUCTION}

Several factors can influence the occurrences of flood events such as land-use change, mainly due to increased imperviousness in urban areas, extreme precipitation events and topographic characteristics of the watershed. Consequences from these events vary for every watershed and depend on a specific analysis for each one. Hydrologic and hydrodynamic studies are necessary for assessments aiming to minimize the impacts of floods on the population. Mitigation of flooding impacts on human activities can be done with techniques to anticipate these events for urban management and planning. Flash floods are rapid events characterized by the occurrence of the peak flow within minutes to few hours after the onset of the rainfall, taking place typically in mountainous regions. Considering cases of steep-slope river basins, for instance, in the Una River Basin in Pernambuco, Brazil, sub-daily runoff predictions are important to flood risk mapping, flood damage assessment and real-time flood forecasting.

Land-use management, floodplain regulation and environmental education are known and applied in several watersheds as flood control methods (Ohana-Levi et al., 2015). Hydrological and hydrodynamic simulation models are widely used for flood planning. These models can simulate historical flood events and search for similarities in current events, allowing the mitigation of negative impacts (Li et al., 2018), such as damage in structures (houses, buildings, transportation infrastructure, and others) and business interruption. Dantas et al. (2014) and Ribeiro Neto et al. (2015) have developed floodplain mapping using daily precipitation data for extreme events in 2000 and 2010 in the Una River Basin (URB). In the present study, these models were applied in other precipitation events for the same basin, allowing new perspectives in natural disaster management, especially in flash flood simulation. In some regions of the URB, the time interval between a precipitation event and its corresponding peak flow is less than one day. The term flash flood refers to these events, especially when highly intense rainfall occurs in mountainous areas with a rapid response for flood occurrence and only a few hours of warning. Flash floods are usually localized disasters, causing more damage, and amplifying social and economic impacts (Boithias et al., 2017; Matingo et al., 2018). The short time of concentration in these hydrological studies demands sub-daily data records for precipitation and streamflow.

The simulation of extreme rainfall events is very difficult due to the large number of parameters involved in hydrological and hydrodynamic modeling. Thus, model calibration and validation are necessary to reduce uncertainties in these simulations (Ballesteros et al., 2011; Habert et al., 2016). Calibration allows adjustment of the model parameters and validation verifies the capacity of the model to represent the physical processes of the watershed by 
comparing simulated and observed data. The gap of in situ data during the peak flow in flood events is a limitation for hydrological simulations. This can be explained by the unexpected magnitude of the values in the extreme events, and failures found in the equipment register. Hydrological and hydrodynamic studies have advantages, such as providing an easy implementation of the physical characteristics of the watershed with a fast and low-cost approach. However, the low quality of the observed data is an obstacle for model calibration and validation. Some limitations of hydrological and hydrodynamic models are the scale of the area, numerical solution approximations, and even erroneous parametrization of the model that do not represent the real physical processes in the study region (Amponsah et al., 2016).

Several cities of Pernambuco state-Brazil are impacted by flood events, which result in increased vulnerability of the riverine population. In the last decade, specifically in 2010, 2011, and 2017, many severe flash floods in these regions were identified. This study deals with aspects that in general are not treated in other similar applications. One example is the combination of medium drainage area and steep slopes that results in great discharges and high flow velocity. These characteristics of the floods in the URB have as a consequence significant impacts to cities sited along the course of the rivers. Other aspects of sub-daily simulations can be highlighted. Part of the river basins in regions with intense rainfall have a short time of concentration. Since conventional rain and stream gauges generate daily records, the flow simulated with these data hides the real behavior of the peak flow, which is significantly greater than the daily average. Among other problems, this difference can affect the extension of floodplain mapping. Rainfall-runoff simulation using sub-daily data supports the operational planning of reservoirs for flood control and the process of generation of scenarios of inundation and flood warning. In the flash flood context of the Una River Basin, the objective of the study is to explore and assess a sub-daily hydrological and hydrodynamic modeling for the more significant events in 2011 and 2017. This approach allows us to use the model as a tool of forecasting and monitoring systems for extreme flood events.

\section{METHODOLOGY}

\subsection{Study Area and Data Acquisition}

The study area selected for the modeling was the Una River Basin, located on the South coast of Pernambuco state (Figure 1), with two regions presenting distinct climate characteristics: Agreste (sited in the upper-medium part of the basin) and Zona da Mata (sited in the medium-lower part). The main course of the Una River extends for approximately 290 $\mathrm{km}$ in an area of $6786 \mathrm{~km}^{2}$. In the Agreste region, the annual mean precipitation ranges from $600 \mathrm{~mm}$ to $800 \mathrm{~mm}$, while the Zona da Mata region presents an annual mean varying between $1500 \mathrm{~mm}$ and $2000 \mathrm{~mm}$. The precipitation increases from Western to Eastern, where the annual mean value is about $2000 \mathrm{~mm}$ on the coast. The upper part of the URB has intermittent rivers due to the semiarid characteristics of the climate. In the medium and lower parts, the flow regime is perennial, and the peak flows are more pronounced (CONDEPE, 2006).

The representation of the geometry of the Una River was made with a digital terrain model (DTM), obtained in a survey using the LiDAR (Light Detection and Ranging) technique, which uses laser beams emitted from an aircraft to scan the river area and its surroundings (approximately $1 \mathrm{~km}$ on each side of the river). The DTM has a spatial resolution of $0.5 \mathrm{~m}$ and an elevation accuracy of $15 \mathrm{~cm}$ (Ribeiro Neto et al., 2015). The Shuttle Radar Topography Mission DTM was used for the pre-processing of the sub-basins using the extension HECGeoHMS. The SRTM DTM has 30 meters of spatial resolution, and it is provided by the Earth Explorer US Geological Survey.

In this study, precipitation, streamflow and water levels time series were obtained from stations of hydrometeorological networks that belong to the National Water Agency (ANA), the National Centre for Monitoring and Early Warning of Natural Disasters (CEMADEN) and 
the Pernambuco Water and Climate Agency (APAC). Daily precipitation is measured in the APAC's stations, totaling 26 in 2011 and 41 in 2017. Sub-daily precipitation data exhibited intervals of 10 minutes (CEMADEN-37 stations), and 15 minutes (ANA-11 stations) in 2017, and 1 hour in 2011 (ANA-4 stations). Considering that 2011 had only four stations with subdaily precipitation data, a routine for conversion of daily in hourly rainfall data was applied. The daily volume of precipitation is distributed throughout the day, taking into account the same temporal distribution of the nearest sub-daily rain gauge. Stream gauges (streamflow and water level) belong to the ANA's network with hourly data for Palmares (drainage area of $4,910.0 \mathrm{~km}^{2}$ ) and Catende (drainage area of $718.0 \mathrm{~km}^{2}$ ) (Figure 1).
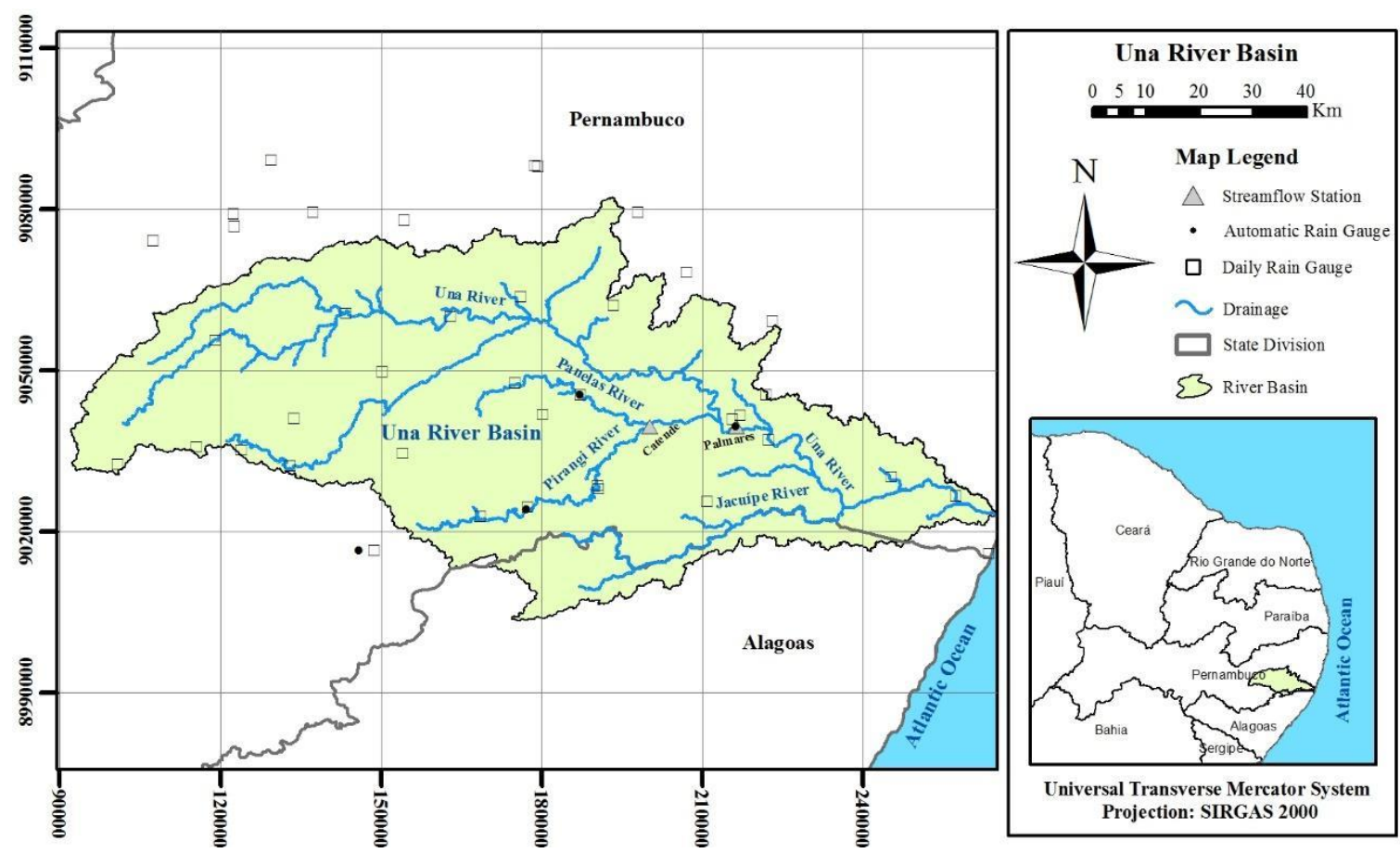

Figure 1. Una River Basin including the main rivers, reaches of the study and in situ stations.

\subsection{Hydrological Model}

The Hydrologic Engineering Center-Hydrologic Modeling System (HEC-HMS) was used in this study, having as reference previous studies (Dantas et al., 2014; Ribeiro Neto et al., 2015; Alves and Cirilo, 2017) performed with daily time step. The main reasons for choosing the HEC-HMS model are: i) ability to simulate high temporal resolution precipitation data; ii) efficient coupling with the hydrodynamic model HEC-RAS; iii) it is a free tool for research purposes; and iv) a number of successful applications worldwide (P.C. et al., 2019 and references cited by them). The pre-processing tasks consist of watershed discretization on subbasins, creation of network elements (reaches and streams), calculation of physical characteristics of the basin such as terrain slope, channel slope, channel length and drainage area. Besides precipitation data and watershed discretization with its network elements, control specifications define the period from beginning to the end of the event simulations. Great floods registered in May 2011 and May 2017, with hourly and 15-minute time-interval data, respectively, were chosen for the modeling. The next step included the representation of the meteorological processes involved in the watershed simulation described by the meteorology model in HEC-HMS. The mean precipitation per sub-basin was calculated using the inverse distance squared method.

Table 1 shows the methods used to represent the hydrological processes in the sub-basins and the respective parameters. The process of runoff generation in the watersheds was 
represented by the Soil Moisture Accounting Loss (SMA) method, which considers losses by infiltration and deep percolation, and the representation of the water storage in three layers of the soil. The excess rainfall calculated by the SMA method was transformed into a runoff with the application of the Snyder Synthetic Unit Hydrograph Model (Snyder UH). Unit Hydrograph Models (UH) theories are largely known and applied for several hydrological studies (Yue and Hashino, 2000; Harto Br et al., 2012). The UH models establish the direct runoff hydrograph produced by the effective rainfall spatially distributed and constant intensity in a specified unit of time.

Table 1. Methods used to represent the hydrological processes.

\begin{tabular}{ccl}
\hline Basin Element & Method & Parameters \\
\hline Canopy & Simple Canopy & Initial and maximum storage \\
\hline Surface & Simple Surface & Initial and maximum storage \\
Loss & $\begin{array}{c}\text { Soil Moisture } \\
\text { Accounting }\end{array}$ & $\begin{array}{l}\text { Initial soil storage, soil storage capacity, soil percolation, impervious, } \\
\text { initial groundwater, groundwater storage capacity, groundwater } \\
\text { percolation, maximum infiltration rate }\end{array}$ \\
\hline Transform & Snyder UH & Lag time and peak coefficient \\
\hline Baseflow & Linear Reservoir & Initial baseflow and groundwater coefficient \\
\hline Routing & Muskingum-Cunge & Manning coefficient \\
\hline
\end{tabular}

Equation 1 shows the computation routine for a direct runoff with the UH model in the HEC-HMS. The discharge at the outlet of the basin is obtained by multiplying the excess rainfall by the UH ordinate discretized in pulses for each time interval.

$\mathrm{Q}_{\mathrm{n}}=\sum_{\mathrm{m}=1}^{\mathrm{n} \leq \mathrm{M}} \mathrm{P}_{\mathrm{m}} \mathrm{U}_{\mathrm{n}-\mathrm{m}+1}$

Where:

$\mathrm{Q}_{\mathrm{n}}$ is the discharge at time $\mathrm{n} \Delta \mathrm{t}$

$\mathrm{P}_{\mathrm{m}}$ is the excess rainfall depth from the time interval $\mathrm{m} \Delta \mathrm{t}$ until $(\mathrm{m}+1) \Delta \mathrm{t}$

$\mathrm{M}$ is the total number of discrete rainfall pulses

$\mathrm{U}_{\mathrm{n}-\mathrm{m}+1}$ is the ordinate $\mathrm{UH}$ at the time $(\mathrm{n}-\mathrm{m}+1) \Delta \mathrm{t}$.

$\mathrm{Q}_{\mathrm{n}}$ and $\mathrm{P}_{\mathrm{m}}$ are expressed as discharge and depth, and $\mathrm{U}$ has dimensions of discharge per unit depth. The input data for the Snyder UH model is lag time in hours, and the peak coefficient, which is related to the hydrograph slope that results from a unit precipitation. In this study, the lag time was calculated, taking $60 \%$ of the time of concentration from each subbasin. The Kirpich method (Equation 2) was used to calculate the time of concentration in the sub-basins. The peak coefficient typically ranges from 0.4 to 0.8 , with lower values associated with steep-rising hydrographs. It was estimated in a trial-and-error process during the model calibration.

$\mathrm{t}_{\mathrm{c}}=57 \cdot\left(\frac{\mathrm{L}^{3}}{\mathrm{H}}\right)^{0.385}$

Where

$t_{c}$ is the time of concentration in min

$\mathrm{L}$ is the length of the largest watercourse in $\mathrm{km}$

$\mathrm{H}$ is the altitude difference between the highest and lowest points of the largest watercourse 
in meters

\subsection{Hydrodynamic Model}

Following hydrological modeling and calibration of the HEC-HMS, the sub-daily analysis of the extreme flood events in the URB was performed with the HEC-RAS (Hydrologic Engineering Center-River Analysis System) hydrodynamic model. Two types of hydrodynamic simulations were conducted. The first one consisted of one-dimensional (1D) simulation, using high-resolution DTM to represent the geometry of the rivers (cross-sections and channel bottom slope). There is only one parameter, Manning's roughness coefficient, that represents the energy loss. The reaches simulated in the HEC-RAS 1D mode and the cross sections are shown in Figure 2. The upstream and lateral inflow boundary conditions come from the HEC-HMS simulations. The downstream boundary condition was the tide variation calculated using harmonic constants of the region near the mouth of the Una River. The second approach of the HEC-RAS used in this study incorporated the two-dimensional (2D) capability for flow routing. The HEC-RAS 1D and 2D models were prepared with the HEC-GeoRAS extension, which is used to build the cross-sections, the course of the rivers, extract the geometry of the terrain, and create the 2D flow area computational mesh.

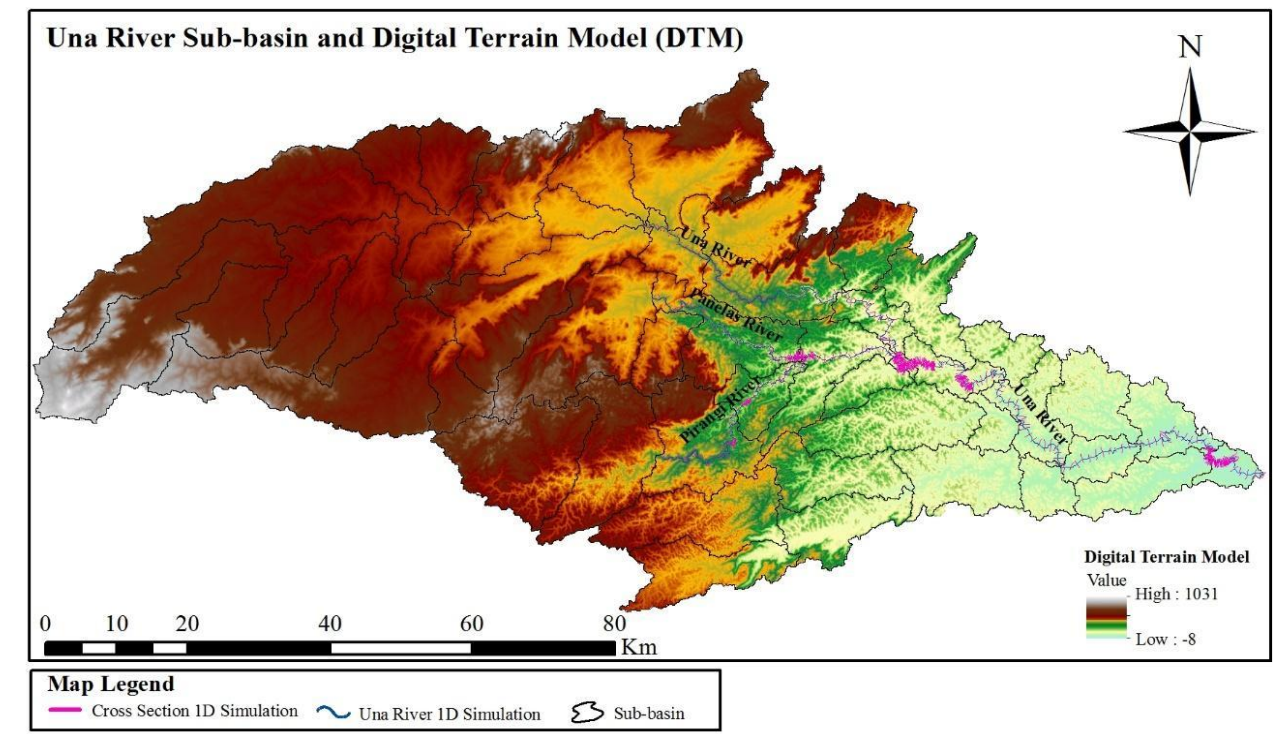

Figure 2. Simulated reaches and the cross sections in the HEC-RAS 1D model.

Unsteady flow components with subcritical flow regimes in 1D and 2D simulations are similar for the representation of the river's natural conditions. Unsteady flow routing from HEC-RAS added the continuity and momentum equations known as Saint Venant or Diffusion Wave equations (USACE and HEC, 2016). In 2D simulations, the HEC-RAS considers a gridded terrain model approach to represent the flow in two possible directions. In the 1D unsteady flow model solution, some issues are connected to instabilities of simulations, such as rapid changes in depth, area, and velocity between neighboring cross-sections due to the steepness of the channel at some reaches. USACE and HEC (2016) exposed several options to solve these cases of instabilities. One of them is the possibility of increasing the Manning's coefficient values in reaches where critical depths and steep channel bottom slopes occur. Another solution is the 2D simulations for flow routing. These solutions were executed in combination with the hydrodynamic model calibration.

\subsection{Model Calibration}

Part of the model parameters was estimated based on physical characteristics of the basins

Rev. Ambient. Água vol. 15 n. 5, e2556 - Taubaté 2020 
and other parts estimated in the process of calibration, comparing measured and simulated hydrographs. One of the parameters calibrated was the Snyder UH peak coefficient, in which there is no direct physical measurement in watersheds. The HEC-HMS model calibration was performed initially for the largest flood event in 2017, using pluviograph data and then applied for the 2011 event.

Three criteria were used to evaluate the simulations: i) Nash-Sutcliffe efficiency (NSE); ii) percent bias (Pbias), which measures the average tendency; and iii) RSR, the ratio between RMSE and the standard deviation of the measured values (STDV $\left.{ }_{\mathrm{obs}}\right)$, where RMSE is the root mean square error. The NSE (Equation 3) is equivalent to linear regression calculated by the coefficient of determination $\mathrm{R}^{2}$, with variation between 0 and 1 . However, NSE may vary from $-\infty$ to 1 , where the values lower or equal to zero do not fit to the observed values. Pbias and RSR were calculated with Equations 4 and 5. The best value of Pbias is zero. Negative values indicate an overestimation of the calculated variable, while positive values indicate underestimation.

$$
\begin{aligned}
& \text { NSE }=1-\left(\frac{\sum_{\mathrm{i}=1}^{\mathrm{n}}\left(\mathrm{q}_{\mathrm{o}}(\mathrm{i})-\mathrm{q}_{\mathrm{s}}(\mathrm{i})\right)^{2}}{\sum_{\mathrm{i}=1}^{\mathrm{n}}\left(\mathrm{q}_{\mathrm{o}}(\mathrm{i})-\mathrm{q}_{\mathrm{ave}}(\mathrm{i})\right)^{2}}\right) \\
& \text { Pbias }=\frac{\sum_{\mathrm{i}=1}^{\mathrm{n}}\left(\mathrm{q}_{\mathrm{o}}(\mathrm{i})-\mathrm{q}_{\mathrm{s}}(\mathrm{i})\right)}{\sum_{\mathrm{i}=1}^{\mathrm{n}}\left(\mathrm{q}_{\mathrm{o}}(\mathrm{i})\right)} \\
& \text { RSR }=\frac{\text { RMSE }}{\operatorname{STDV}_{\mathrm{obs}}}=\frac{\sqrt{\sum_{\mathrm{i}=1}^{\mathrm{n}}\left(\mathrm{q}_{\mathrm{o}}(\mathrm{i})-\mathrm{q}_{\mathrm{s}}(\mathrm{i})\right)^{2}}}{\sqrt{\sum_{\mathrm{i}=1}^{\mathrm{n}}\left(\mathrm{q}_{\mathrm{o}}(\mathrm{i})-\mathrm{q}_{\mathrm{ave}}(\mathrm{i})\right)^{2}}}
\end{aligned}
$$

Where $\mathrm{n}$ is the number of samples, $\mathrm{q}_{\mathrm{o}}(\mathrm{i})$ is the observed streamflow, $\mathrm{q}_{\mathrm{s}}(\mathrm{i})$ is the simulated streamflow and qave is the average observed streamflows. Moriasi et al. (2007) developed an analysis to recommend values of accuracy for hydrological simulations. Although Moriasi et al. (2007) indicate a classification for monthly time-step simulations, we took it into account as a first reference to evaluate the quality of the sub-daily simulations.

The calibration of the HEC-RAS model was performed with the estimate of the Manning's roughness coefficient, pursuing physically coherent values and stable simulations. The hydrodynamic model was validated with the observed water level time series of the Palmares stream gauge (shown in Figure 1). The entire methodological procedure is described in Figure 3.

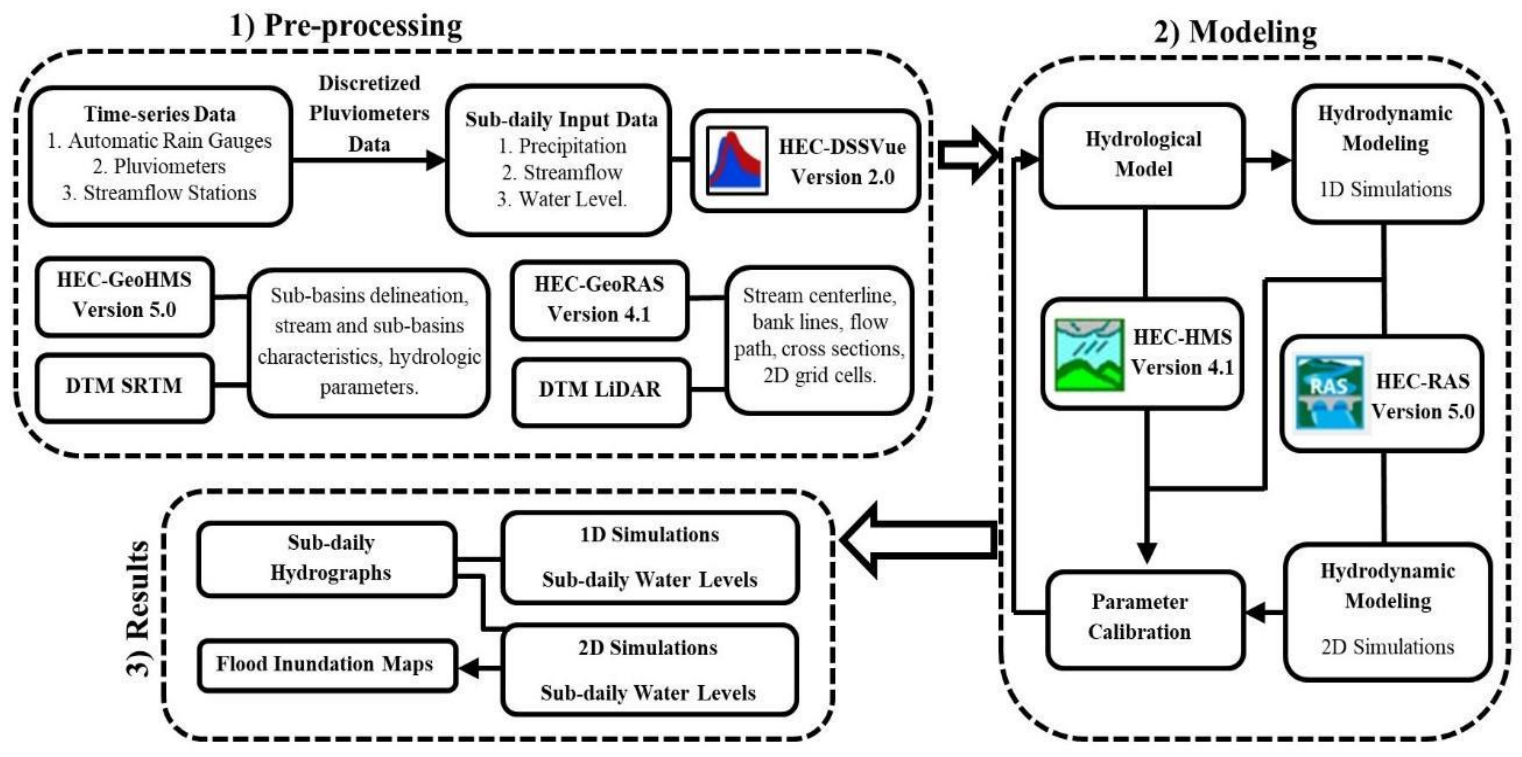

Figure 3. Methodological procedure. 


\section{RESULTS AND DISCUSSION}

\subsection{Hydrological Modeling}

The previous daily HEC-HMS simulations in the URB were performed with the SCS UH method to transform the excess rainfall in runoff. The same method applied in a sub-daily simulation generates great values of discharge due to its way of calculating the peak flow. The decision to use Snyder UH aimed to overcome this problem. The parameters of infiltration and peak coefficient (from the Snyder UH method) presented the greatest sensitivity in the calibration process of sub-daily event-based simulations. Figure 4 shows the simulated and observed streamflow of the stations Catende and Palmares for the events of May 2017 and May 2011. Table 2 shows the values of the criteria used to evaluate the calibration of the HEC-HMS. According to the classification of Moriasi et al. (2007), the simulation performance can be considered between good and very good (RSR and NSE), which reflects the agreement between the hydrographs simulated and observed after the calibration of the HEC-HMS model. Pbias had unsatisfactory values for Palmares in May 2017 due to disagreement between the hydrographs at the end of the recession. There is no data to represent the peak flow in the 2017 event because the water level rose beyond the validated segment of the rating curve, i.e., water level is available, but streamflow not.

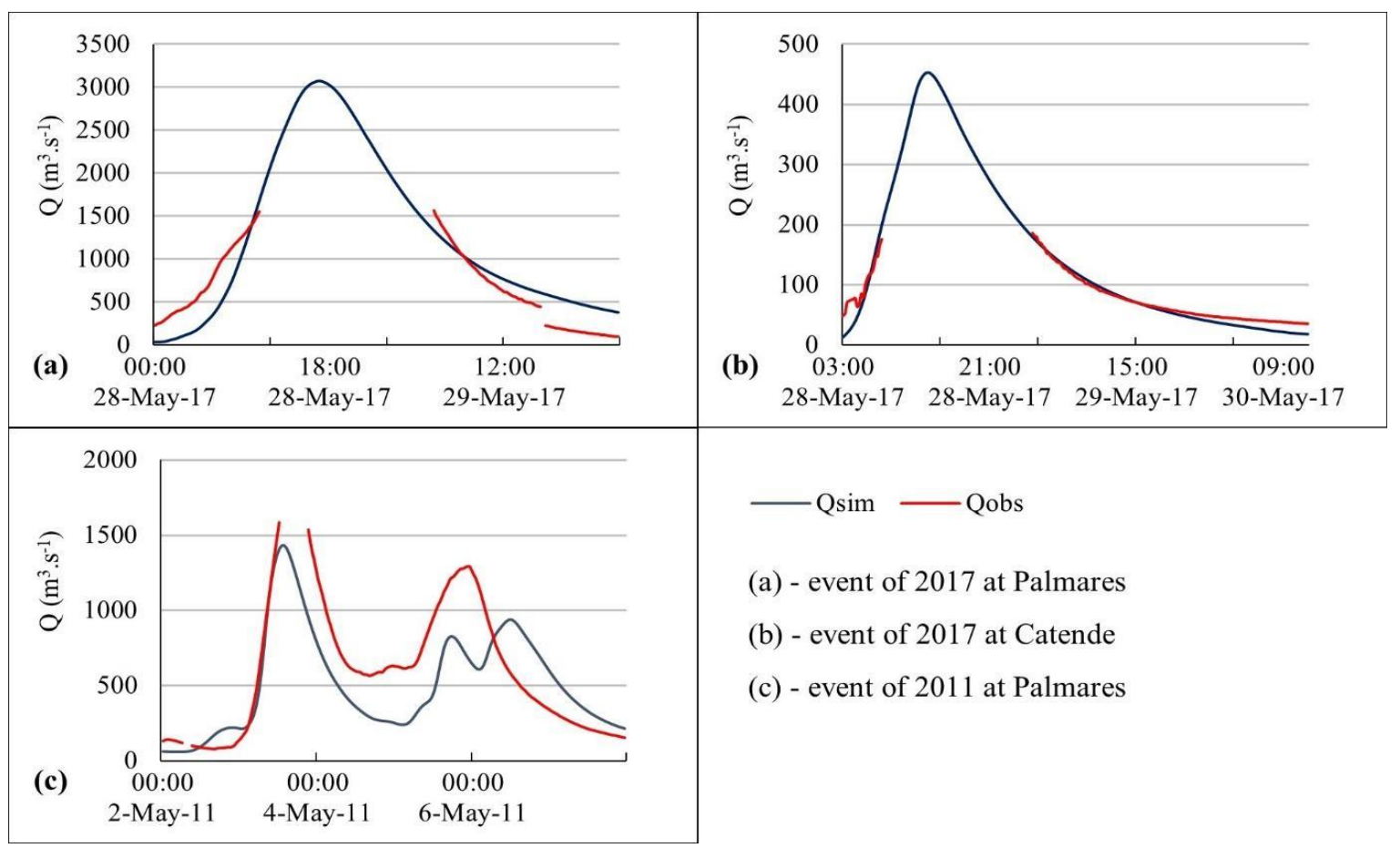

Figure 4. Streamflows observed $\left(\mathrm{Q}_{\mathrm{obs}}\right)$ and simulated $\left(\mathrm{Q}_{\mathrm{sim}}\right)$ with HEC-HMS.

Table 2. Calibration performance.

\begin{tabular}{ccccc}
\hline Station & Date & RSR & NSE & Pbias (\%) \\
\hline Catende & $28 / 05 / 2017$ & 0.46 & 0.78 & 20.5 \\
Palmares & $28 / 05 / 2017$ & 0.57 & 0.68 & -34.1 \\
Palmares & $03 / 05 / 2011$ & 0.58 & 0.64 & -4.9 \\
\hline
\end{tabular}

The number of rain gauges with sub-daily data available in 2011 was limited for the hydrological simulations, as they did not cover the entire Una River Basin. For this reason, the use of discretized data from daily rain gauges made it possible to perform the sub-daily 
simulation. Palmares was the only stream gauge with observed data for comparison in the 2011 event. The simulation performance was good according to two criteria, presenting NSE and RSR with good approximation between the observed and simulated data. Pbias had a slight tendency to underestimate the observed streamflow. This was noticeable in the hydrograph recession of the first peak flow and in the rise of the second peak (Figure 4c).

The results obtained with discretized data from daily rain gauges can be considered satisfactory after the calibration of the 2011 event. It is worth mentioning again that the classification proposed by Moriasi et al. (2007) has been based on monthly simulation, while the simulation presented here used a one-hour time step. In this case, all event results were accepted as satisfactory for the continuity of the following steps of the hydrodynamic modeling. There are not many studies that deal with hydrological simulation in watersheds with similar characteristics to URB, i.e., a medium-size drainage area and steep slope. Simulations using HEC-HMS have been very successful in small basins and rainfall representations with highresolution radar (P.C. et al., 2019; Mejía-Veintimilla et al., 2019), and, in some cases, in mountainous regions (Tu et al., 2020; Mejía-Veintimilla et al., 2019). Similar applications were not found in medium-sized basins. The better performance found in these studies in comparison to URB can be explained by the accurate representation of the spatial distribution of the precipitation using meteorological radar.

\subsection{Hydrodynamic Modeling}

The first approach considered in the modeling with HEC-RAS utilized a one-dimensional scheme according to prior studies that adopted a daily time step (Dantas et al., 2014; Ribeiro Neto et al., 2015). The reaches simulated in the URB are shown in Figure 1. In the prior studies, the results of the daily simulations were satisfactory; however, without information about the streamflow and water level behavior over the hours. The sub-daily one-dimensional simulation showed a considerable lag between the simulated and observed peak flows. Differently from the streamflow data, there was sub-daily water level data available without missing values. The sub-daily one-dimensional simulation allowed us to verify a delay of the simulated flood wave of 12 hours in the 2017 event and 7 hours in 2011. Due to this delay, the sub-daily onedimensional simulation was considered unsatisfactory according to the criteria of Moriasi et al. (2007). The peak lag occurred due to numerical instabilities of the solution for the subcritical flow regime with exacerbated water level variation between the cross-sections. The reduction of the Manning's coefficient attenuated the difference of the peak time occurrence, but, at the same time, the streamflow and the water level reduced substantially.

Steep slope rivers represent a great difficulty for hydrodynamic simulation in unsteady flow regimes. The one-dimensional solution is suitable for gradually varied flow, which is not observed in steep slope rivers. In those cases, there are reaches where there occurs rapidly varied flow with transitions from subcritical to supercritical flow and hydraulic jumps. The floods in the Una River have high water velocity and variation in reaches with a steep slope. The analysis of the one-dimensional simulation shows great changes in the hydraulic variables (water velocity, depth and area) in neighboring cross-sections, hindering a stable solution of the HECRAS 1D. For this reason, we performed two-dimensional simulation.

From Version 5.0, the HEC-RAS incorporated tools for two-dimensional hydrodynamic modeling. The software solves the Saint-Venant equations in its two-dimensional form with an implicit finite volume solution algorithm. According to USACE (2016), this method allows the solution of complex computational problems in less time than the explicit methods, and the two-dimensional hydrodynamic problems are solved with more stability and robustness. Figure 5 shows the computational grid cells for the two-dimensional modeling at the city of Palmares in Pernambuco state (only this area was simulated). The upstream boundary condition was the discharge simulated by the HEC-HMS model. 


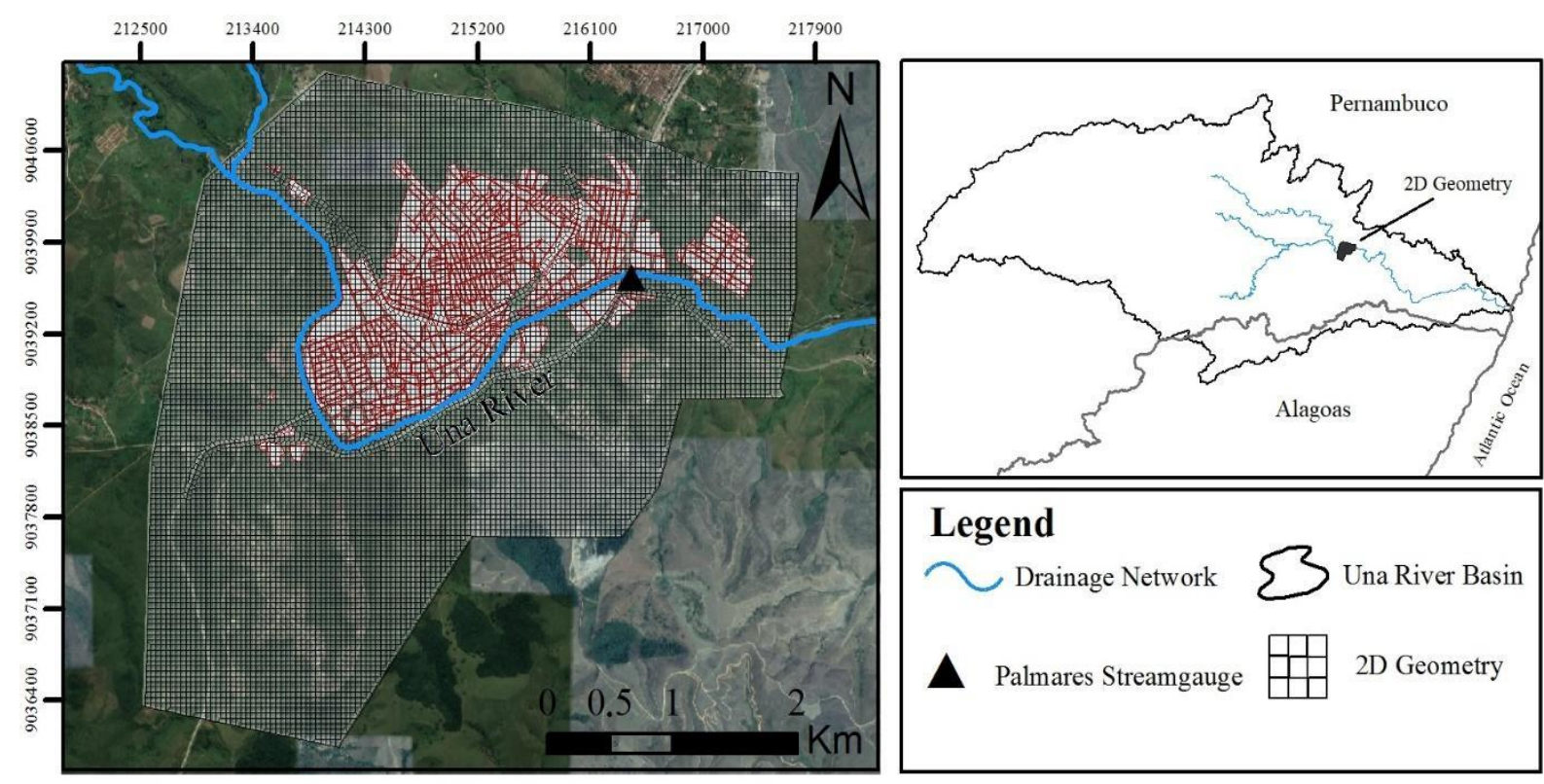

Figure 5. Computational grid cells for the two-dimensional modeling at the city of Palmares.

The result after HEC-HMS and HEC-RAS 2D simulations is shown in Figure 6, where the simulated and observed values of the peak time and the corresponding water level are also presented. In the 2011 event, the peak time and the water level simulated were the same in the first flood wave (03/05/2011). On the other hand, the water level in the rising of the first peak and in the descending water after the second peak were overestimated (Figure 6a). The water level simulated in the 2017 event also had the same value as the observed level. However, the time of the simulated peak occurred one hour before the real value. Similar to the 2011 event, the HEC-RAS 2D overestimated the water level in the descending part of the limnigram. There was an opportunity to evaluate the extension of the flood through the comparison of the map generated by HEC-RAS and information obtained in the field after the 2011 event. There was a good agreement between the maps (shown in Figure 7a), except for the central area, where the inundation estimated by the model spread beyond the limit surveyed in the field. The survey was carried out by the Geological Survey of Brazil (CPRM). The flood mapping of the 2017 event is shown in Figure 7b. In the absence of the observed flooding extent in extreme events, as occurred in 2017, the simulated flood mapping can be a reference for decision makers in charge of actions related to disaster management.

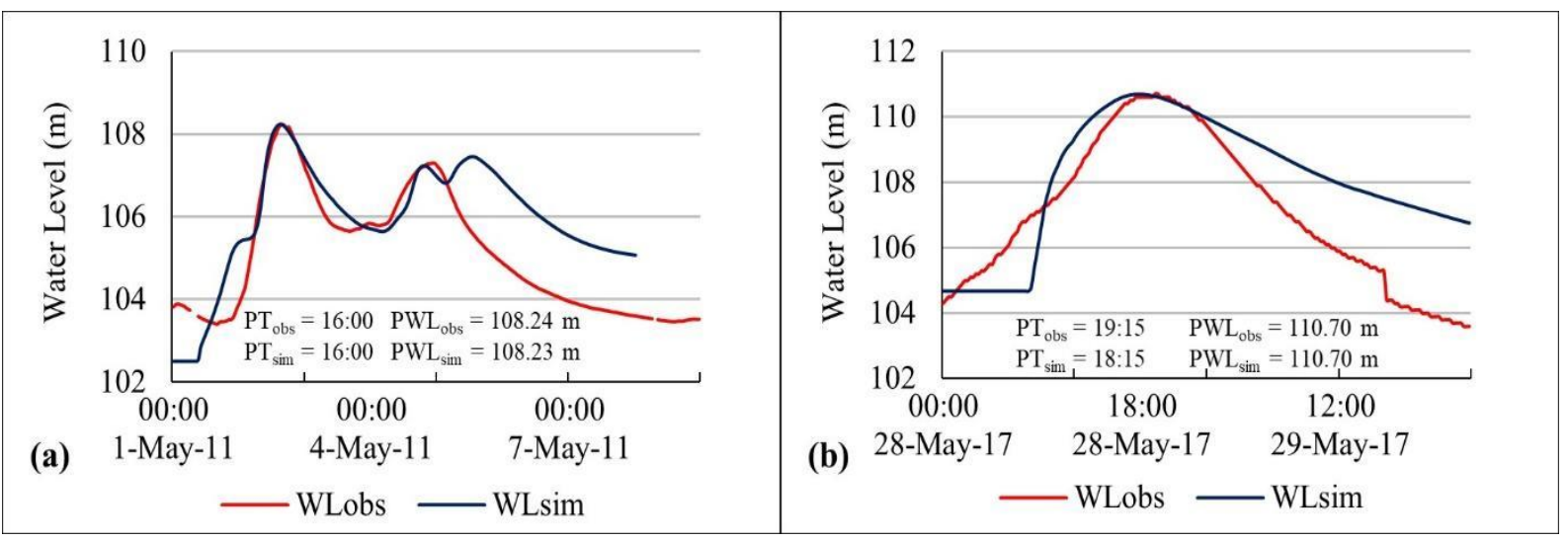

Figure 6. Water level simulated (WLsim) and observed (WLobs) in May 2011 (a) and May 2017 (b) at

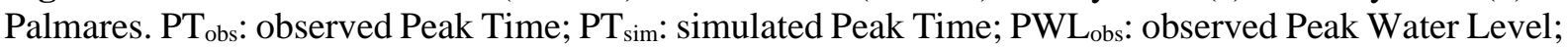
PWL $_{\text {sim: }}$ simulated Peak Water Level. 

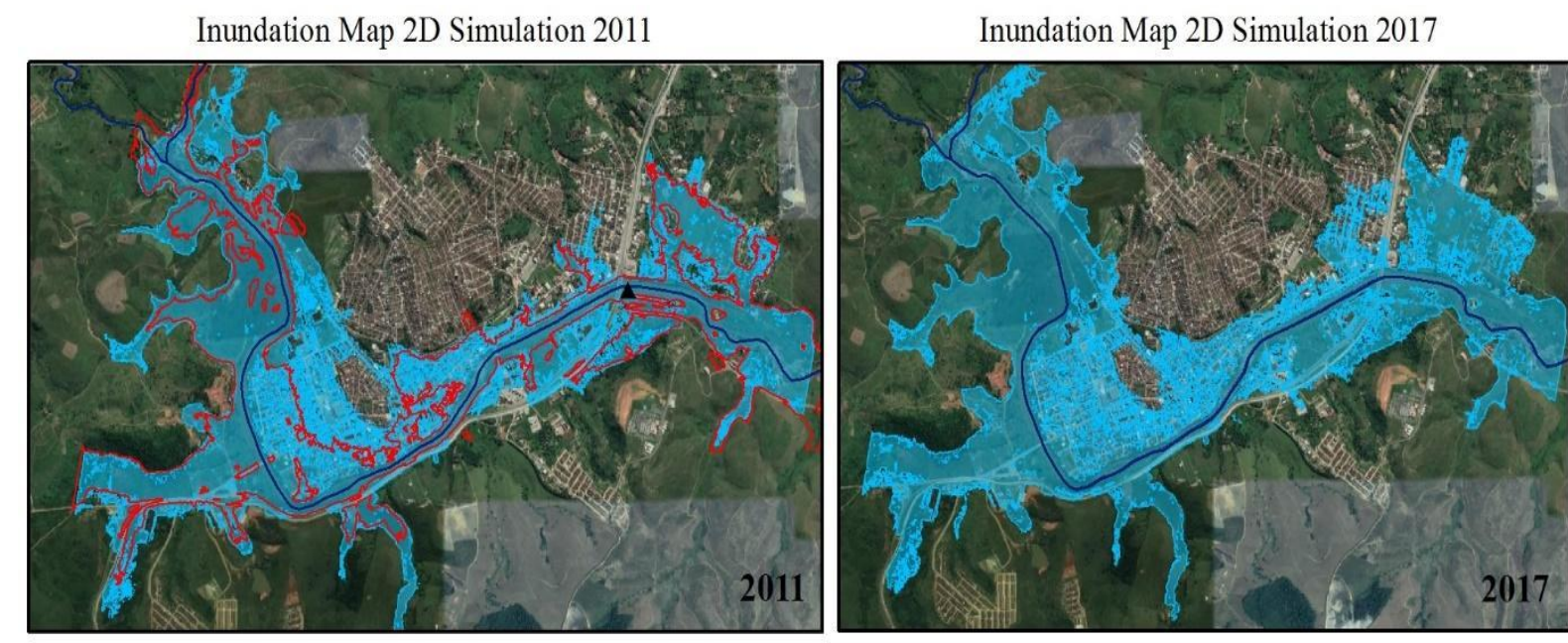

Legend

$\curvearrowleft$ Una River

$\Delta$ Palmares Station

Observed Inundation Limits 2011

Simulated Inundation Limits

Figure 7. Flood mapping of the 2011 event (with in situ survey) and 2017 event.

\section{CONCLUSIONS}

Hydrological HEC-HMS model calibration performance pointed to good efficiency of the Una River flash flood simulations with hourly and sub-hourly (15 minutes) time steps. Automatic rain gauges and discretized pluviometers data allowed knowing in detail peak flow during the day of the flood events. The hydrological calibration using rain gauge data proved satisfactory for simulation in different flood events. The conversion of daily rainfall to hourly time steps using an automatic rain gauge was shown to be reliable and could be used when subdaily data are not available.

The steep regions in the URB were the main factor of instabilities for the 1D hydrodynamic model solution. The HEC-RAS computation routine for 1D unsteady flow was not enough to describe the propagation of flood waves satisfactorily. Thus, 2D simulations provided flood wave propagation in the 2011 and 2017 events with a good approximation of the peak time and flow.

HEC-HMS and HEC-RAS models with sub-daily simulations allowed us to identify deficiencies non-observed in daily time-step simulations. In the case of the hydrological model, a previous method (SCS UH) for the transformation of excess rainfall in runoff was tested during the modeling. This methodology tends to generate great discharges with time steps lower than one day. The Snyder UH method solved this problem, being suitable for sub-daily simulations. In the case of the hydrodynamic model, there was a great discrepancy between observed and simulated data in terms of peak time representation over the day when 1D simulations were performed. This inconsistency was settled with the $2 \mathrm{D}$-simulations model scheme.

\section{ACKNOWLEDGMENTS}

This article is a contribution of the project "Medidas Adaptativas para Enfrentamento de Eventos Climáticos e Hidrológicos Extremos no Estado de Pernambuco" (contract FADE/UFPE n. 104/2017) and the Brazilian Network on Global Climate Change Research Rede CLIMA (Grant 01.13.0353-00). 


\section{REFERENCES}

ALVES, F. H. B.; CIRILO, J. A. Comparativo das precipitações dos eventos extremos de 2010 e 2017 ocorridos na bacia do rio Una em Pernambuco e estimativa dos efeitos de barragem de contenção de cheias. In: SIMPÓSIO BRASILEIRO DE RECURSOS HÍDRICOS, 2017, Florianópolis. Proceedings[...] Florianópolis: ABRH, 2017.

AMPONSAH, W.; MARCHI, L.; ZOCCATELLI, D.; BONI, G.; CAVALLI, M.; COMITI, F.; CREMA, S.; LUCÍA, A.; MARRA, F.; BORGA, M. Hydrometeorological characterization of a flash flood associated with major geomorphic effects: assessment of peak discharge uncertainties and analysis of the runoff response. American Meteorological Society, v. 17, p. 3063-3077, 2016. https://doi.org/10.1175/JHM-D-160081.1

BALLESTEROS, J. A.; BODOQUE, J. M.; DÍEZ-HERRERO, A.; SANCHEZ-SILVA, M.; STOFFEL, M. Calibration of floodplain roughness and estimation of flood discharge based on tree-ring evidence and hydraulic modeling. Journal of Hydrology, v. 403, n. 1-2, p. 103-115, 2011. https://doi.org/10.1016/j.jhydrol.2011.03.045

BOITHIAS, L.; SAUVAGE, S.; LENICA, A.; ROUX, H.; ABBASPOUR K. C.; LARNIER, K.; DARTUS, D.; SÁNCHEZ-PÉREZ, J. M. Simulating flash floods at hourly time-step using the SWAT model. Water, v. 9, n. 929, p. 1-25, 2017. https://doi.org/10.3390/w9120929

CONDEPE. Bacia hidrográfica do rio Una, quarto e quinto grupos de bacias hidrográficas de pequenos rios litorâneos - GL 4 e GL 5. Recife, 2006. 85 p.

DANTAS, C. E. O.; RIBEIRO NETO, A.; CIRILO, J. A.; DANTAS, C. E. O.; SILVA, E. R. Caracterização da formação de cheias na bacia do rio Una em Pernambuco: Análise estatística regional. Revista Brasileira de Recursos Hídricos, v. 19, n. 4, p. 239-248, 2014.

HABERT, J.; RICCI, S.; LE PAPE, E.; THUAL, O.; PIACENTINI, A.; GOUTAL, N.; JONVILLE, G.; ROCHOUX, M. Reduction of the uncertainties in the water leveldischarge relation of a $1 \mathrm{D}$ hydraulic model in the context of operational flood forecasting. $\begin{array}{lllllll}\text { Journal of Hydrology, } & \text { v. 532, p. }\end{array}$ https://doi.org/10.1016/j.jhydrol.2015.11.023

HARTO BR, S.; YUDIYANTI, I. T.; COENRAAD, R. Performance of representative unit hydrograph derived from different number of cases. Journal of the Civil Engineering Forum, v. 21, n. 2, p. 1243-1248, 2012. https://doi.org/10.22146/jcef.18930

LI, D.; QU, S.; SHI, P.; CHEN, X.; XUE, F.; GOU, J.; ZHANG, W. Development and integration of sub-daily flood modelling capability within the SWAT model and a comparison with XAJ model. Water, v. 10, n. 1263, p. 1-17, 2018. https://doi.org/10.3390/w10091263

MATINGO, T.; GUMINDOGA, W.; MAKURIRA, H. Evaluation of sub daily satellite rainfall estimates through flash flood modelling in the Lower Middle Zambezi Basin. Proceedings of the International Association of Hydrological Sciences, v. 378, p. 5965, 2018. https://dx.doi.org/10.5194/piahs-378-59-2018 
MEJÍA-VEINTIMILLA, D.; OCHOA-CUEVA, P.; SAMANIEGO-ROJAS, N.; FÉLIX, R.; ARTEAGA, J.; CRESPO, P.; OÑATE-VALDIVIESO, F.; FRIES, A. River Discharge Simulation in the High Andes of Southern Ecuador Using High-Resolution Radar Observations and Meteorological Station Data. Remote Sensing, v. 11, 2019. https://dx.doi.org/10.3390/rs11232804

MORIASI, D. N.; ARNOLD, J. G.; LIEW, M. W. V.; BINGNER, R. L.; HARMEL, R. D.; VEITH, T. L. Model evaluation guidelines for systematic quantification of accuracy in watershed simulation. American Society of Agricultural and Biological Engineers, v. 50, n. 3, p. 885-900, 2007. https://dx.doi.org/10.13031/2013.23153

OHANA-LEVI, N.; KARNIELI, A.; EGOZI, R.; GIVATI, A.; PEETERS, A. Modeling the effects of land-cover change on rainfall-runoff relationships in a semiarid, Eastern Mediterranean watershed. Advances in Meteorology, p. 1-16, 2015. https://doi.org/10.1155/2015/838070

P.C., S.; NAKATANI, T.; MISUMI, R. The Role of the Spatial Distribution of Radar Rainfall on Hydrological Modeling for an Urbanized River Basin in Japan. Water, v. 11, n. 1703, 2019. https://doi.org/10.3390/w11081703

RIBEIRO NETO, A.; CIRILO, J. A.; DANTAS, C. E. O.; SILVA, E. R. Caracterização da formação de cheias na bacia do rio Una em Pernambuco: Simulação hidrológicahidrodinâmica. Revista Brasileira de Recursos Hídricos, v. 20, n. 2, p. 394-403, 2015.

UNITED STATES. Army. Corps of Engineers; HYDROLOGIC ENGINEERING CENTER. HEC-RAS River Analysis System: Hydraulic Reference Manual: Version 5.0. Davis, 2016. $547 \mathrm{p}$.

TU, H.; WANG, X.; ZHANG, W.; PENG, H.; KE, Q.; CHEN, X. Flash Flood Early Warning Coupled with Hydrological Simulation and the Rising Rate of the Flood Stage in a Mountainous Small Watershed in Sichuan Province, China. Water, v. 12, 2020. https://dx.doi.org/10.3390/w12010255

YUE, S.; HASHINO, M. Unit hydrographs to model quick and slow runoff components of streamflow. Journal of Hydrology, v. 227, p. 195-206, 2000. https://doi.org/10.1016/S0022-1694(99)00185-7 